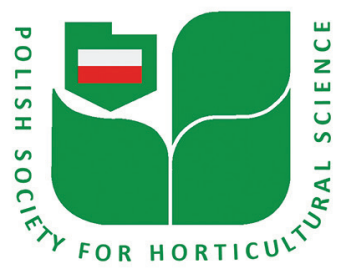

Folia Hort. 32(2) (2020): 291-305

\title{
Effects of shoot age on biological and chemical properties of red currant (Ribes rubrum L.) cultivars
}

\author{
Boban S. Djordjevic ${ }^{1, *}$, Dejan B. Djurovic ${ }^{1}$, Gordan D. Zecl, Mekjell O. Meland ${ }^{2}$, \\ Milica M. Fotiric Aksic
}

\author{
${ }^{1}$ Faculty of Agriculture, University of Belgrade, Nemanjina 6, 11080 Belgrade, Serbia \\ ${ }^{2}$ Norwegian Institute of Bioeconomy Research (NIBIO), Ullensvangvegen1005, N-5781 Lofthus, Norway
}

\begin{abstract}
The aim of this study was to examine the influence of shoot age on biological and chemical properties of 11 red currant cultivars ('Jonkheer van Tets', 'Junifer', 'London Market', 'Makosta', 'Mirana', 'Redpoll', 'Rolan', 'Rondom', 'Rovada', 'Slovakia' and 'Stanza') with different origins and ripening times. Phenological observations and pomological characteristics were studied and chemical analysis was conducted from 2013 to 2018 at experimental fields near Belgrade, Serbia. The total contents of phenols and anthocyanin were estimated spectrophotometrically, while quantitative analysis of anthocyanin aglycones was done using high-performance liquid chromatography. Three-year-old shoots had an earlier start of all examined phenological stages, better generative potential, higher yields, as well as higher total phenol and vitamin $\mathrm{C}$ contents in the fruits, compared with 2 -year-old shoots, for all cultivars. The contents of total anthocyanins were higher in berries on younger shoots of early-ripening cultivars, while late-ripening cultivars had higher contents of total soluble solids and cyanidin in the berries on 3-year-old shoots. Principal component analysis demonstrated that the most important variables that distinguished 2-year-old shoots from 3-year-old shoots were those related to phenological data, cluster traits, total acids and yields. According to the obtained results, 'Junifer' (with the highest number of clusters), 'Mirana' (with the highest sugar content and sugar/acid ratio), 'Redpoll' (with the highest physical traits of cluster and berry), 'Slovakia' (with the highest yield and yield efficiency) and 'Rovada' (with the highest level of secondary metabolites) are recommended as the most promising cultivars for growing in the temperate region of Serbia.
\end{abstract}

Keywords: anthocyanin, fruit quality, phenology, phenols, principal component analysis, yield, yield efficiency

\section{INTRODUCTION}

Currants belong to the genus Ribes, which includes $>150$ species concentrated mainly in the northern temperate regions. Only 3-4 species (Ribes sativum Syme, Ribes petraeum Wulf. and Ribes rubrum L.) of the Ribes genus are cultivated for red currant fruit production (Brennan, 2008). Red currant (Ribes rubrum L.) is native to parts of Western Europe and is cultivated in home gardens and commercial plantations in the moderate temperature regions of Central and Eastern Europe (Yang et al., 2013). In the period from 2015 to 2018, global currants production ranged between 540000 to 663000 tones. The top five producers of currants in the world are the Russian Federation, Poland, Ukraine, France and Germany (FAOSTAT, 2020). Compared with other fruit species, the management of currants is not demanding and its cultivation gives producers high returns on investment and profitability (Djordjević et al., 2014). Although red currants are native to Serbia, their production has been negligible and mainly organised sporadically in some small pockets. However, over the last several years, the 
area under red currant production has been increasing (Milošević and Milošević, 2018). Red currants are mostly used for fresh consumption and in many processed products (juices, jams and preserves; pie fillings, dessert toppings; yoghurts, ice creams; mineral water, tea, and liqueurs; candies and perfumes) (Milivojevic et al., 2012). The seeds of currants are used for the production of gamma-linolenic acid (Šavikin et al., 2013).

Shrub size, ripening time, berry size and yield differ among the various cultivars of currants (Paprstein et al., 2016). Increased number of long annual shoots affected the yield and fruit quality of red currants, together with the percentage of the most suitable fruits for fresh marketing (Karhu et al. 2020). Large yield of currants is correlated with the vigour and the age of the shoots, flower bud formation in the previous season and berry size (Heijerman and Gessel, 2020; Sønsteby et al., 2017). Quantitative and qualitative properties of the fruits differ among cultivars, as well as with age of plants, environment conditions, cultivation systems, different pre- and post-harvest factors, ripening stage of berries and the number of clusters (Mikulic-Petkovsek et al., 2016: Ersoy et al., 2018). Xu et al. (2016) recorded that the ageing of roots in raspberry had a significant effect on yield and percentage of marketable fruits. They observed that shoots from younger roots produced more marketable fruits and also lower yield compared to shoots from older roots.

Berries, including currants, are important dietary sources of sugars, acids, fibres, vitamins, minerals, phenolics, aromatic volatile compounds and other antioxidant molecules that have high health benefits for human (Hidalgo and Almajano, 2017; Gündeşli et al., 2019). The organoleptic properties and the nutritional values are important for the commercial value of berries and berry products. Cultivars of red currant show significant variations in the contents of sugars and acids, because of the strong influence of their geographical origins (Pantelidis et al., 2007). The amounts of primary metabolites (sugars and acids), which are responsible for the sweetness of the fruit, have a significant influence on the quality of berries and thus on consumer acceptance (Zheng et al., 2009). The main sugars are fructose and glucose, while citric and malic acids are the dominant acids (Milivojevic et al., 2012). Berries of red currant cultivars have significantly higher contents of ascorbic acid compared to other soft fruits (Ciornea et al., 2009). The content of ascorbic acid in berries of red currant cultivars ranged between 29.3 and $71.2 \mathrm{mg} \cdot 100 \mathrm{~g}^{-1}$ fresh weight (Zdunic et al., 2016). Many previous studies have proven that the antioxidant activity of currant fruits is due to their high ascorbic acid content (Orsavova et al., 2019).

Moreover, the fruits, leaves and seeds of currants contain certain phenolic compounds, such as anthocyanins, catechins, proanthocyanidins, flavonols and hydroxycinnamic acids and other non-coloured flavonoids (Djordjevic et al., 2010; Šavikin et al., 2013; Mikulic-Petkovsek et al., 2016), which make them an interesting target for the functional food industry. The anthocyanins are water-soluble pigments and their content in currants depends on several factors, such as weather during the growing season, harvesting time and fruit maturity, but mostly on the genetic predisposition (Stanus et al., 2019; Berk et al., 2020). The most frequently occurring anthocyanidin in red currant berries is cyanidin, and the common sugars bonded to anthocyanidins are glucose, xylose and rhamnose (Veberič et al., 2015). Among the flavonols, quercetin glycosides have been reported as the major component in berries of red currant cultivars (Yang et al., 2013). These components have remarkable effects on the survival, growth and differentiation of cells. Their effects include antioxidant, anti-allergic, anti-inflammatory, antiviral, anti-proliferative, anti-mutagenic, antimicrobial and anti-carcinogenic activities, giving protection from cardiovascular damage and allergy (Santos-Buelga et al, 2014; Okatan, 2020).

To the best of our knowledge, similar research on red currant cultivars has not been done so far. So, this study aimed to evaluate the influence of the age of the shoots on biological and chemical properties of red currant cultivars adopted for Serbian or other temperate climatic conditions.

\section{MATERIALS AND METHODS}

\section{Plants and berries}

In this study, 11 red currant cultivars, namely 'Jonkheer van Tets' (Jvt), 'Junifer' (Jun), 'London Market' (Lok), 'Makosta' (Mak), 'Mirana' (Mir), 'Redpoll' (Red), 'Rolan' (Rol), 'Rondom' (Ron), 'Rovada' (Rov), 'Slovakia' (Slo) and 'Stanza' (Sta), were evaluated over a 6-year period (2013-2018). The experimental fields were located in Mislođin village near Belgrade, Serbia, between $44^{\circ} 30^{\prime}$ and $44^{\circ} 45^{\prime}$ north latitudes. The altitude was between 80 and $90 \mathrm{~m}$.Mislođin is located almost in the centre of the northern warm temperate belt, with a climate milder and more continental than that of typical Pannonia. The average annual temperature in this area is about $11^{\circ} \mathrm{C}$, and the amount of annual rainfall is about $640 \mathrm{~L} \cdot \mathrm{m}^{-2}$. Planting was done in spring 2007 with 1-year-old bushes, with distances of $1.8 \mathrm{~m}$ between rows and $0.8 \mathrm{~m}$ within the row, on sandy loam soil type with average $\mathrm{pH}$ 6.1. The orchards were managed according to the integral cultivation system. During the drought season, drip irrigation was used. During the vegetative phase, contact herbicides were used for weed control. At the beginning of the growing seasons, $200 \mathrm{~kg} \cdot \mathrm{ha}^{-1}$ mineral fertiliser (N-P-K, 14-7-17) was applied. Cattle manure was applied every third year $\left(10.0 \mathrm{~kg} \cdot \mathrm{m}^{-2}\right)$. The experiment was organised randomly with five repetitions (four bushes per repetition). On each bush, three 2-year-old and three 3-year-old shoots were left after winter pruning. Berries were hand-harvested in the months of June-July, depending on the commercial ripening time for each cultivar $(90 \%$ fruit surface colour). 


\section{Phenological observations}

According to the UPOV (The International Union for the Protection of New Varieties of Plants) Code for Ribes_Rub (2012), the following phenological properties were studied: bud burst (when $10 \%$ of total buds showed burst), beginning of flowering ( $10 \%$ open flowers) and harvesting time (when the fruit starts to be easily removable from the plant). For all cultivars, the beginning of bud burst, the beginning of flowering and the harvesting time were recorded on 3-year-old shoots and were compared with the properties of 2-year-old shoots.

\section{Generative traits}

The following generative traits were evaluated: cluster weight, cluster length, number of flowers per cluster, number of berries per cluster, berry weight and fruit set (number of fruits per 100 flowers), number of clusters per shoot and bush, and yield per shoot and bush. The total weights of the clusters and the berries were measured and expressed in grams, whereas cluster length was measured with a ruler and expressed in centimetres. Measurements included both types of shoots.

A new generative parameter for red currant, the 'Yield efficiency' (YE) of the cultivar, is defined. This parameter shows the number of clusters required for having a 1-kg yield per bush. The equation for calculating the $\mathrm{YE}$ is given below:

$$
\mathrm{YE}=1000 \mathrm{~g} /(\mathrm{BW} \times \mathrm{NFC} \times \mathrm{FS})
$$

where BW is the berry weight, NFC is the number of flowers per cluster and FS is the fruit set.

\section{Determination of soluble solids, titratable acidity, sugars and vitamin $C$}

After harvesting, the berries were stored at $3^{\circ} \mathrm{C}$ and analysed within $24 \mathrm{~h}$. In total, $500 \mathrm{~g}$ of undamaged berries were selected and manually crushed to obtain juices. For analyses, the juices were centrifuged at $14,000 \times g$ for $20 \mathrm{~min}$. The total soluble solid (TSS) content of the berries was determined by using a refractometer (pocket PAL-1; Atago, Kyoto, Japan). Titratable acidity (TA) was determined by titrating the berry juice with $0.1 \mathrm{~N} \mathrm{NaOH}$ up to $\mathrm{pH}$ 7.0. Acidity was expressed as the percentage of malic acid. Total sugars (TS), invert sugar (IS) and sucrose (SUC) levels were determined by the Luff-Schoorl method in percentage. Vitamin C was quantified using the reflectometer set of Merck Co. (Merck RQflex, Darmstadt, Germany). Fruit sample (5 g) and $20 \mathrm{~mL}$ oxalic acid (1\%) were mixed, homogenised for $1 \mathrm{~min}$ and filtered. Polyvinylpolypyrrolidone (PVPP) $(500 \mathrm{~g})$ was added to $10 \mathrm{~mL}$ of the filtered sample to remove phenols, and 6-7 drops of $\mathrm{H}_{2} \mathrm{SO}_{4}(25 \%)$ were added, to reduce the $\mathrm{pH}$ level to $<1.14$. Results were expressed as milligrams of ascorbic acid per $100 \mathrm{~g}$ fresh weight $(\mathrm{FW})$. The primary metabolites were analysed in the whole fruit without seeds. For each cultivar, three repetitions per sampling date were carried out.

\section{Determination of total phenolic content}

The total content of phenols was estimated by the FolinCiocalteu method with slight modifications (Waterman and Mole, 1994). Berries (10 g) were subjected to extraction in an ultrasonic bath with $\mathrm{MeOH}$ for 30 min and then filtered. The extracts $(200 \mu \mathrm{L})$ were then added to $1 \mathrm{~mL}$ of 1:10 diluted Folin-Ciocalteu reagent. After $4 \mathrm{~min}, 800 \mu \mathrm{l}$ of sodium carbonate $\left(75 \mathrm{~g} \cdot \mathrm{L}^{-1}\right)$ was added. After $2 \mathrm{~h}$ of incubation at room temperature, the absorbance at $765 \mathrm{~nm}$ was measured. Gallic acid $\left(0-100 \mathrm{mg} \cdot \mathrm{L}^{-1}\right)$ was used for calibration of a standard curve. The results were expressed as milligrams of gallic acid equivalents (GAE) per 100 g FW (mg $\left.\mathrm{GAE} \cdot 100 \mathrm{~g}^{-1} \mathrm{FW}\right)$.

\section{Total anthocyanin content}

Total anthocyanin content was investigated according to the procedure described in European Pharmacopoeia 6.0 (2008) with slight modifications. Fresh berries $(50 \mathrm{~g})$ were crushed extemporaneously. To about $10 \mathrm{~g}$ of crushed, accurately weighed berries or juice (10 g equivalent of fresh berry), methanol $(95 \mathrm{~mL})$ was added and mechanically stirred for $30 \mathrm{~min}$, then filtered into a $100 \mathrm{~mL}$ volumetric flask. The filtrate was rinsed and diluted to $100 \mathrm{~mL}$ with methanol. A 50-fold dilution of this solution in a $0.1 \% \mathrm{v} / \mathrm{v}$ solution of hydrochloric acid in methanol was prepared. The absorbance of the solution was measured at $528 \mathrm{~nm}$, using a $0.1 \% \mathrm{v} / \mathrm{v}$ solution of hydrochloric acid in methanol as the compensation liquid. The percentage content of anthocyanins, expressed as cyanidin-3-glucoside chloride, was calculated using the following expression:

$$
\text { Anthocyanin }(\%)=(A \times 5000) /(718 \times m)
$$

where $A=$ absorbance at $528 \mathrm{~nm} ; 718=$ specific absorbance of cyanidin-3-glucoside chloride at $528 \mathrm{~nm}$; and $m=$ mass of the substance to be examined [in grams]).

\section{Quantitative analysis of anthocyanin aglycones}

The analysis was performed according to the procedure described by Nyman and Kumpulainen (2001), with slight modifications. About $5 \mathrm{~g}$ of crushed and accurately weighed berries was extracted with $40 \mathrm{~mL}$ of a mixture of $50 \mathrm{~mL} \mathrm{MeOH}, 33 \mathrm{~mL} \mathrm{H}_{2} \mathrm{O}$ and $17 \mathrm{~mL} \mathrm{37 \%}$ $\mathrm{HCl}$ using an ultrasonic bath for $20 \mathrm{~min}$. The extract was filtered through $0.45 \mu \mathrm{m}$ filters into polypropylene vials and hydrolysed for $60 \mathrm{~min}$ in a water bath at $100^{\circ} \mathrm{C}$. After quick cooling, the samples were injected into a high-performance liquid chromatography (HPLC) column. Analyses were carried out on Agilent series 1200 RR system equipped with a diode array detector, on a reversed-phase Lichrospher RP-18 analytical column $(250 \times 4 \mathrm{~mm}$ inner diameter; particle size $5 \mu \mathrm{m}$; Agilent). The mobile phases were $\mathrm{A}\left(\mathrm{H}_{2} \mathrm{O}\right.$ containing $10 \% \mathrm{HCOOH})$ and $\mathrm{B}(\mathrm{MeCN})$. The extracts were separated by gradient elution according to the following scheme: $1 \%$ B $0-0.5 \mathrm{~min} ; 1-7 \%$ B $0.5-$ $1 \mathrm{~min} ; 7 \%$ B $1-4 \mathrm{~min} ; 7-10 \%$ B $4-7.5 \mathrm{~min} ; 10-14 \%$ 
B 7.5-11.5 min; 14\% B 11.5-15.5 min; $14-18 \%$ B $15.5-$ $18.5 \mathrm{~min} ; 18 \%$ B $18.5-22 \mathrm{~min}$. The flow was adjusted to $1 \mathrm{~mL} \times \mathrm{min}^{-1}$ and detection was carried out at 290 , 350 and $520 \mathrm{~nm}$. Quantification was done using the calibration curves of authentic standards (Fluka, Germany).

\section{Statistical analysis}

All data on the phenological properties of the red currant cultivars are presented as mean values \pm standard deviations. The physical attributes of the cluster are presented as the means of five repetitions (20 clusters per repetition) and, for chemical traits, as the means of triplicate determination. The generative properties of the cultivars are presented as the mean of five repetitions (four bushes per repetition). Analysis using a one-way analysis of variance (ANOVA) was done with STATISTICA 9.0 software package. The significant differences between means, determined at $p<0.05$, were measured with LSD (the least significant difference) tests.

Principal component analysis (PCA) was applied to visualise the structure of the data and to identify important variables. PCA was carried out using a demo version of the PLS Toolbox software package for MatLab 7.8.0 (Eigenvector Research, Inc., Wenatchee, WA, USA). All data were group-scaled, i.e. groups of variables were scaled to grand standard deviation, before PCA.

\section{RESULTS AND DISCUSSION}

\section{Phenological observations}

'Junifer' had the earliest beginning of bud (average date) burst, while 'Rovada' had the latest (Figure 1A and 1B). In all cultivars, earlier beginning of bud burst was recorded in 3-year-old shoots compared with 2-year-old shoots. This was probably due to the fact that old shoots possess a higher level of nitrogen and carbohydrate storage, which caused earlier start of vegetation (Palacio et al., 2018). The highest time difference in the beginning of bud burst among 3- and 2-year-old shoots was for Slovakia (6 days) and the lowest was for 'Mirana' (2 days). 'Junifer' and 'Stanza' had the earliest time of flowering for 3 -year-old shoots and the latest was observed for 'Rolan' (Figure 2A and 2B). All cultivars showed delayed flowering time on 2-year-old shoots compared to 3-year-old shoots. 'Rolan', 'Slovakia' and 'Jonkheer van Tets' did not have flower buds on 2-yearold shoots at all. At harvesting, the cultivars were divided into three groups: early ('Junifer', 'Jonkheer van Tets' and 'Stanza'), which ripened from June 9 to 20; medium ('Rondom', 'London Market', 'Rolan' and 'Makosta'), which ripened in the period June 21-28; and late ('Mirana', 'Slovakia', 'Rovada' and 'Redpoll'), which ripened from June 29 up to July 6. Similar results were found by Georgiev et al. (2008), who described similar ripening times for the same cultivars. All cultivars manifested later ripening of berries on

A

Phenological phase buds burst

- 3 years old shoots 1 stdev 3

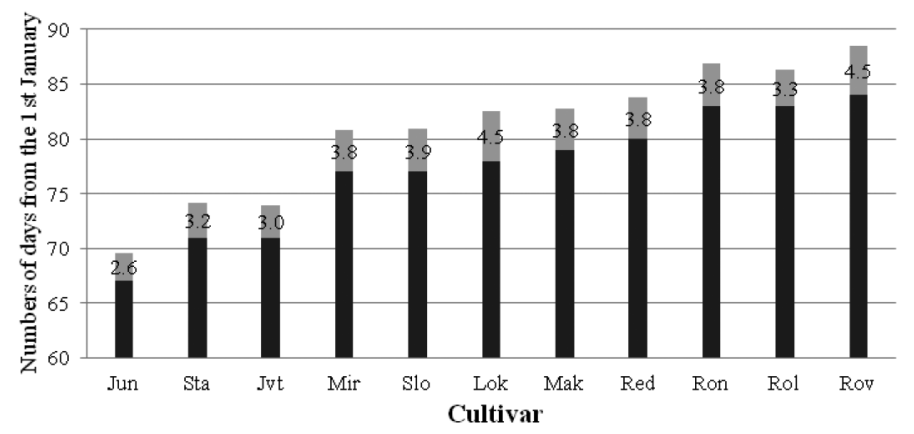

B

Phenological phase buds burst

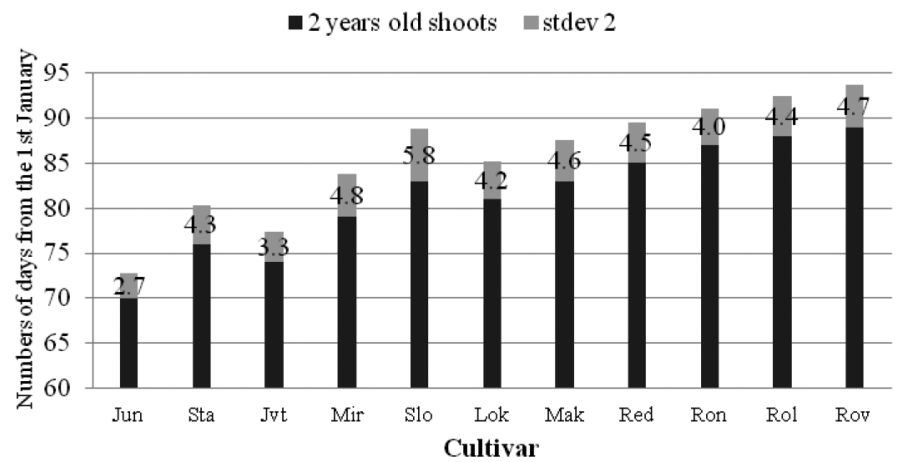

Figure 1. (A) The beginning of bud burst of 3-year-old shoots of red currant cultivars (counting from the 1 st of January); mean \pm standard deviation. (B) The beginning of bud burst of 2-year-old shoots of red currant cultivars (counting from the 1st of January); mean \pm standard deviation. 


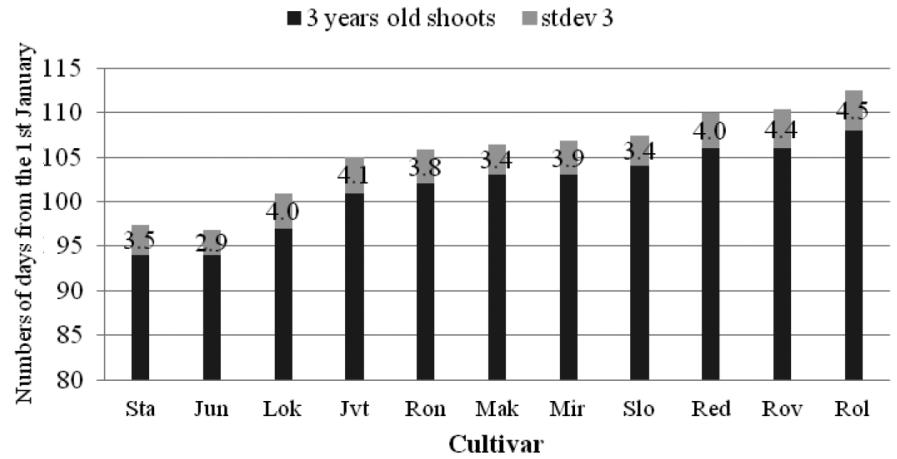

Phenological phase beginning of flowering

- 2 years old shoots 1 stdev 2

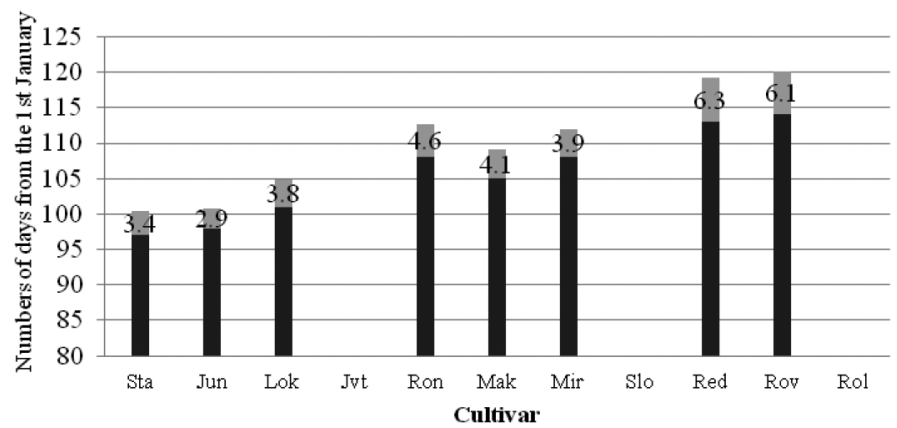

Figure 2. (A) The beginning of the flowering of 3-year-old shoots of red currant cultivars (counting from the 1st of January); mean \pm standard deviation. (B) The beginning of the flowering of 2- to 3-year-old shoots of red currant cultivars (counting from the $1^{\text {st }}$ of January); mean \pm standard deviation.

2-year-old shoots (Figure $3 \mathrm{~A}$ and $3 \mathrm{~B}$ ). The highest difference in the beginning of harvest between 3- and 2-year-old shoots was observed for 'Stanza' (6 days) and the lowest was for 'Mirana' and 'Redpoll' (2 days). Furthermore, cultivars with the highest number of clusters per plant had the largest difference in harvesting times when comparing shoots with different ages. This could be either genotype dependent or due to the vigour and/or the number of clusters per bush.

\section{Generative traits}

Physical attributes of clusters and berries were significantly dependent on shoots' age and cultivars (Table 1). On 2-year-old shoots, the cluster weight ranged between $5.4 \mathrm{~g}$ ('Makosta') and $13.8 \mathrm{~g}$ ('Redpoll'). Cluster weight ranged between $3.6 \mathrm{~g}$ ('London Market') and $13.5 \mathrm{~g}$ ('Slovakia') on 3-yearold shoots. However, all cultivars showed significantly higher results in terms of cluster length, the number of flowers and berries per cluster and the berry weight on 2-year-old shoots. The highest number of berries per cluster was found in 'Redpoll' and 'Slovakia' (24.6 and 21.2, respectively), while 'Jonkheer van Tets' and 'Junifer' (9.1 and 8.7, respectively) had the lowest. This finding confirmed previous reports by Giongo et al. (2008), who had evaluated several red currant cultivars and showed that 'Redpoll' had the highest number of berries compared to other cultivars. The number of berries per cluster was slightly lower than that published by Milivojević et al. (2012) for the same cultivars. The differences between the results could be attributed to the significantly longer life span of the plants studied herein and the different environmental conditions.

The cultivar Rondom (1.02 g) had the largest berry weight, while 'London Market' $(0.32 \mathrm{~g})$ had the lowest. All cultivars, except 'Stanza', had larger berries on 2-year-old shoots, compared to 3-year-old shoots. Marketable berries (diameter $>10 \mathrm{~mm}$ ) were found in 'Junifer', 'Rondom' and 'Mirana' on both types of shoots, in 'Redpoll' on 2-year-old shoots and in 'Slovakia', 'Rolan' and 'Jonkheer van Tets' on 3-yearold shoots. Berries from both 2- and 3-year-old shoots did not yield any marketable fruits in 'Rovada', 'London market', 'Stanza' and 'Makosta'. The fruit set ranged from $66 \%$ to $91.1 \%$ on 2 -year-old shoots and from $70.9 \%$ to $91.8 \%$ on 3 -year-old shoots. The highest percentage of fruit set on 2-year-old shoots was in 'Redpoll' (91.1\%), while 'Slovakia' (91.8\%) had the highest fruit set on 3-year-old shoots. Only 'Stanza' and 'Makosta' had higher fruit sets on older shoots. Fruit set in this experiment was at the same level as reported by Giongo et al. (2008).

All studied cultivars had a higher number of clusters on 3-year-old shoots compared to 2-year-old shoots (Table 2). The highest number of clusters was found in 'Junifer' (142.3) and the lowest number of clusters was in 'Rovada' (53.6). The cultivar 'Junifer' had the 
-3 years old shoots $\|$ stdev

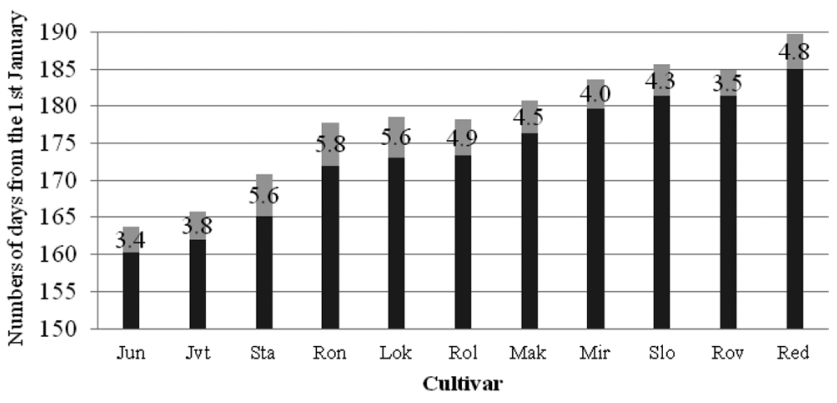

B

Phenological phase beginning of harvesting

- 2 years old shoots $\quad$ stdev

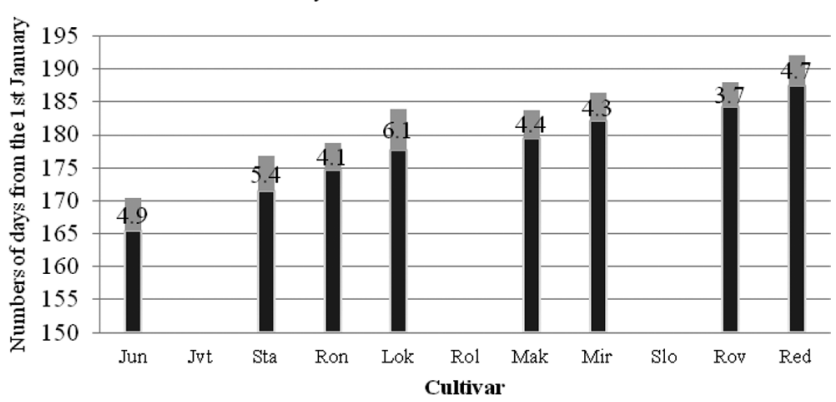

Figure 3. (A) The beginning of the harvesting of 3-year-old shoots of red currant cultivars (counting from the 1 st of January); mean \pm standard deviation. (B) The beginning of the harvesting of 2-year-old shoots of red currant cultivars (counting from the 1 st of January); mean \pm standard deviation.

highest number of clusters on 2-year-old shoots (13). The highest-yielding cultivar was 'Slovakia' (3.9 $\mathrm{kg}$ per bush) despite cluster development only on 2-year-old shoots, while the lowest yield per bush was in 'Makosta' (0.7 kg per bush). The highest yield on 3 -year-old shoots was found in 'Slovakia' (1.29 kg per bush) and 'Mirana' (0.97 kg per bush) and the lowest was in 'Rovada' ( $0.41 \mathrm{~kg}$ per bush) and 'Makosta' ( $0.23 \mathrm{~kg}$ per bush). Cultivars London Market and Junifer were the only two cultivars with $>10 \%$ of the total yield on 2-year-old shoots. Similar results were obtained by Milošević and Milošević (2018), who studied numerous red currant cultivars and showed that 'Slovakia' had the highest yield per bush. But generally, it is known that the yield potential can be modified by unfavourable conditions (mostly temperatures during flowering), some biotic stresses or the nutrition and carbohydrate status of the plant (Krüger et al., 2011).

The highest generative potential, expressed as the total number of clusters per bush, was observed for 'Junifer' (465.89), while the lowest was recorded in 'Rovada' (164.4). However, 'Slovakia' had the highest YE and 'Makosta' had the lowest. To achieve a yield of $1 \mathrm{~kg}$ berries per bush, 'Slovakia' needed 73.9 clusters, while 'Makosta' needed 267.4 clusters.

\section{Determination of soluble solids, TA, sugars and vitamin $C$}

The TSS content varied among cultivars and with shoot age (Table 3 ). The highest average values of
TSS during the period under study were for 'Mirana' $(12.6 \%)$ and the lowest for 'Junifer' $(9.5 \%)$ on 2 - and 3 -year-old shoots. The highest TSS was on older shoots in 'Redpoll' (12.7\%) and on younger shoots in 'Mirana' (12.1\%). Late-ripening cultivars had higher contents of TSS in berries compared to early-ripening cultivars in both types of shoots. Moreover, early-ripening cultivars had higher values of TSS in 2-year-old shoots, while all late-ripening cultivars had higher TSS in 3-yearold shoots. The highest difference in TSS was found between the shoots in cultivars Makosta $(0.80 \%)$ and Redpoll (0.8\%). Kaldmäa et al. (2013) noticed that both genotypes and microclimate conditions significantly influenced the TSS values and that late-ripening cultivars had higher TSS.

'Redpoll' (1.6\%) had the highest level of total acids (TA) and 'Rolan' had the lowest (0.5\%) level of TA. All cultivars had a higher level of TA in the berries on older shoots. A higher yield has a negative influence on bioactive compounds (Krüger et al., 2011; Woznicki et al., 2016). The average values for TA in all red currant cultivars studied herein were 1.5-2.8 folds lower compared to values reported by other researchers (Milošević and Milošević, 2018). The differences between the results could be due to the influence of environmental conditions and agricultural practices. Rubinskiene et al. (2006) and Zheng et al. (2009) proved that environmental conditions, especially temperature, humidity, number of cloudy days and precipitation, have a strong influence on the amount of TA in berries. 


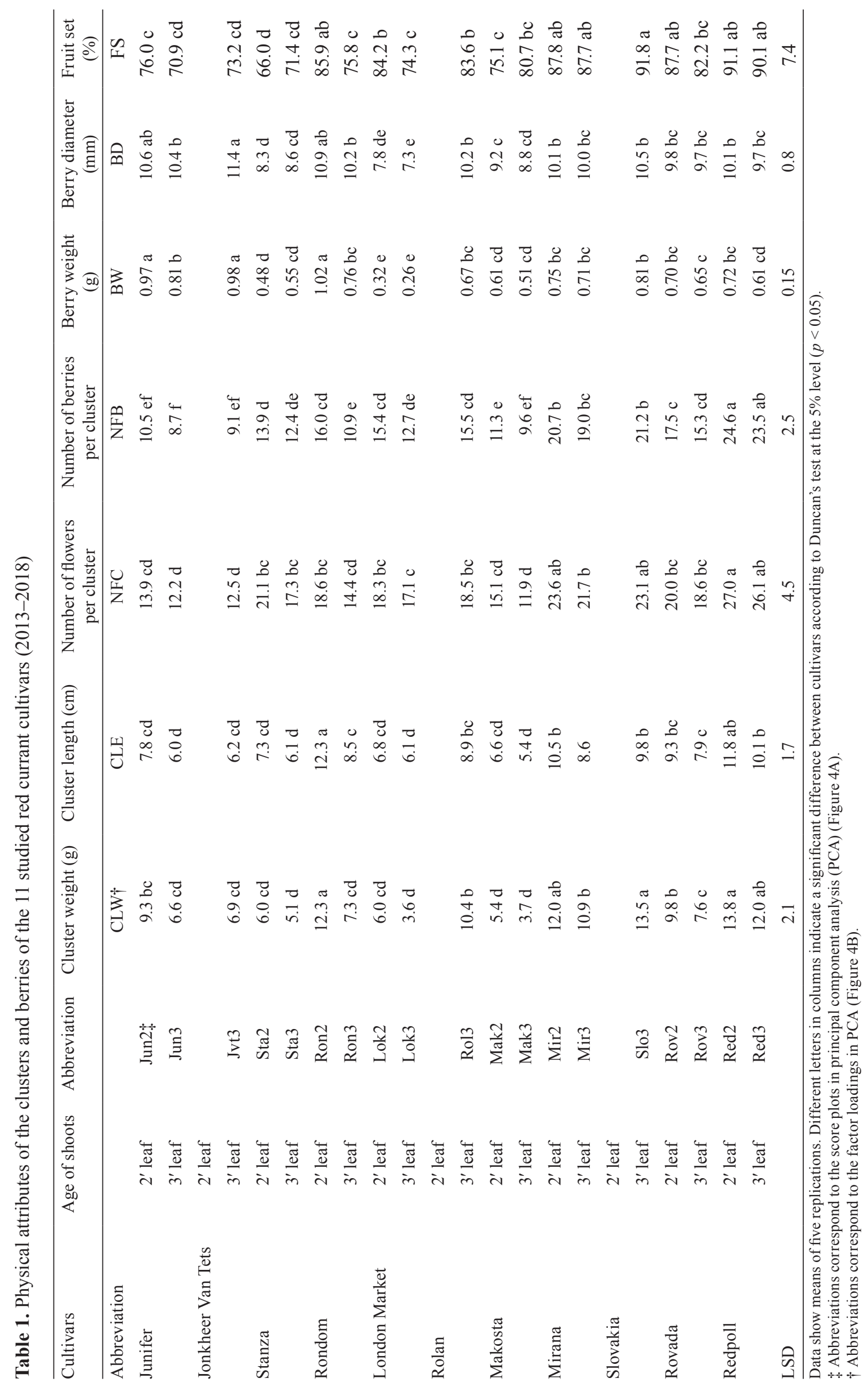




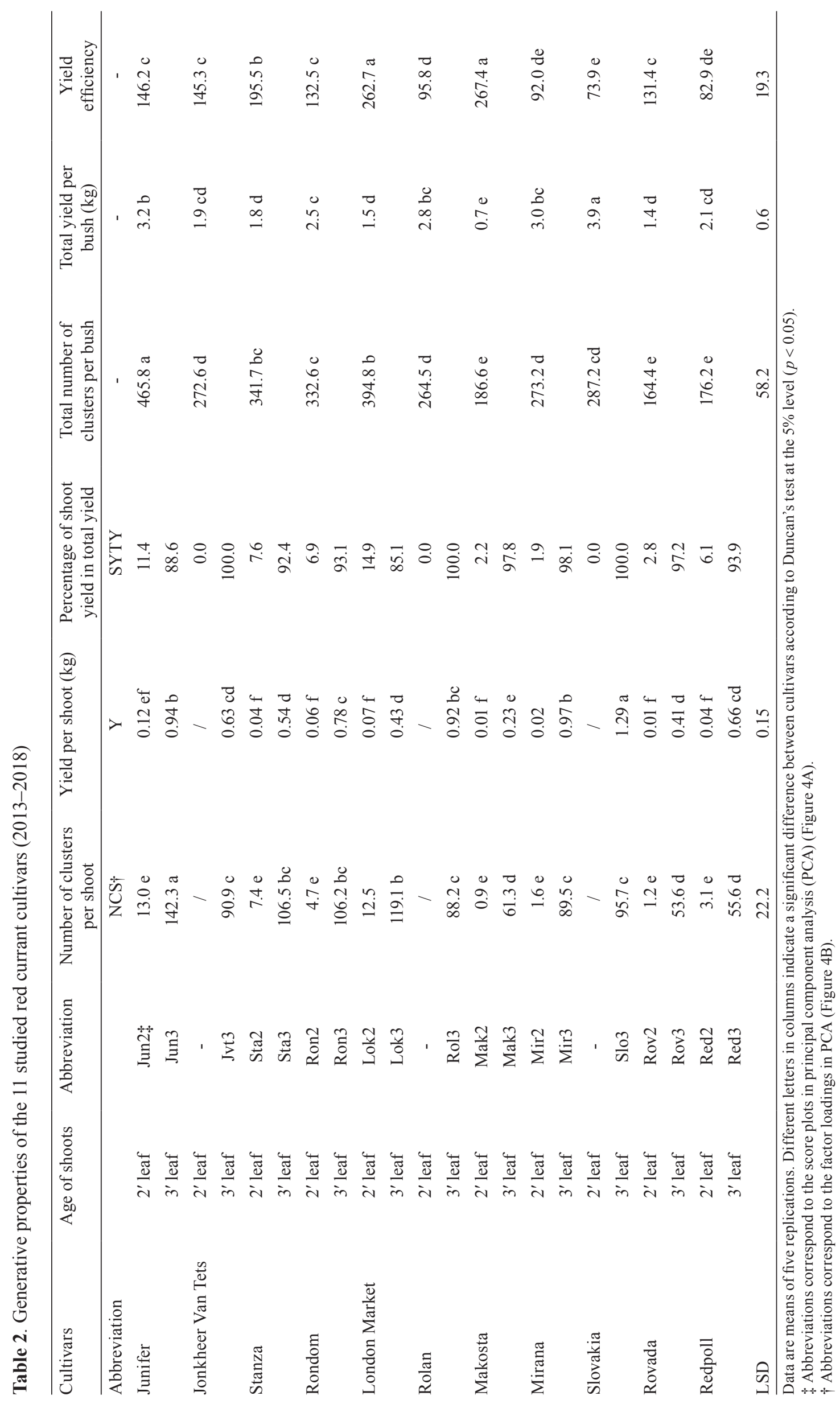




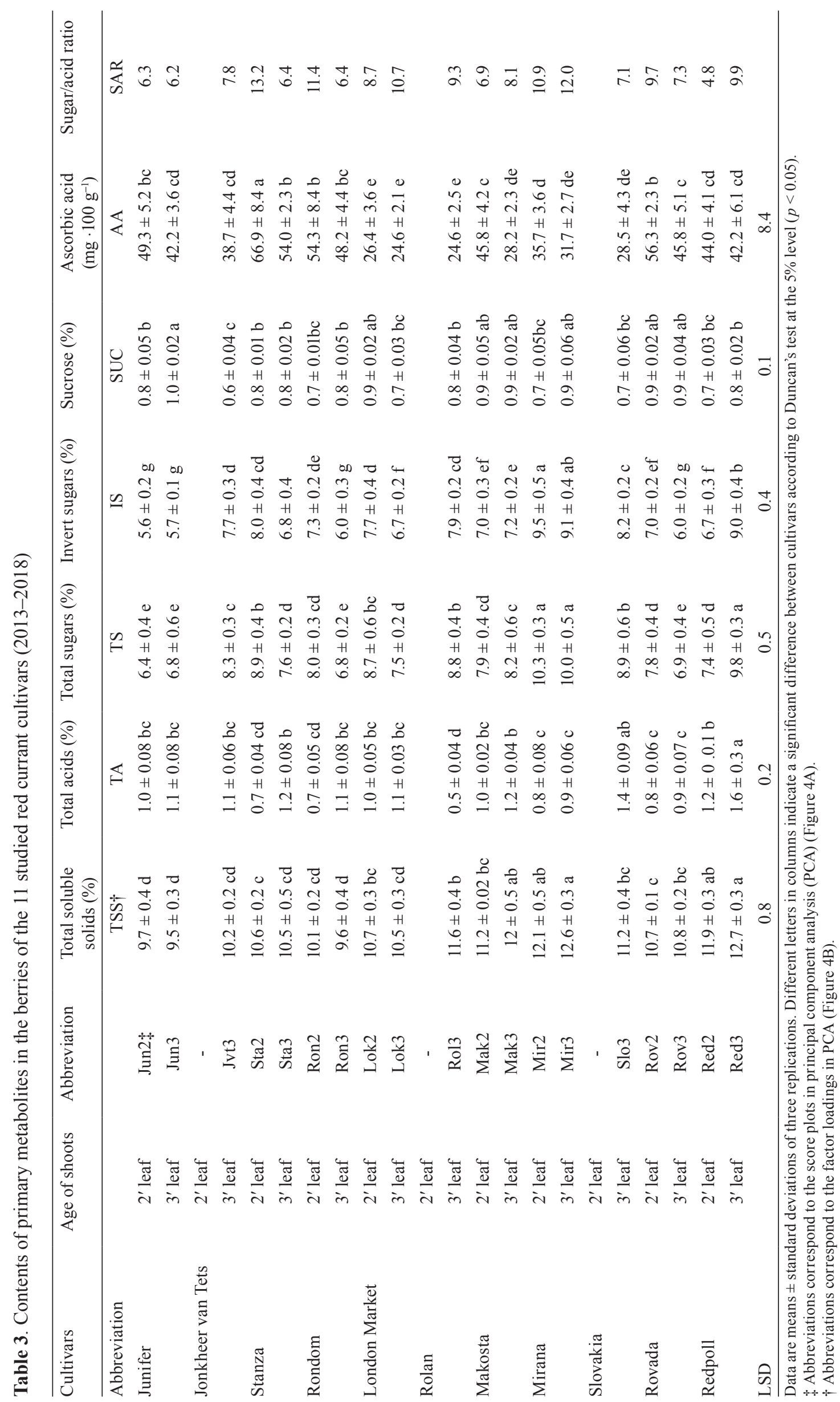


The cultivar Mirana had the highest content of TS $(10.3 \%)$, while 'Junifer' had the lowest (6.4\%). Several cultivars had a higher content of TS on young shoots, which have lower crop load. Milivojević et al. (2012) recorded a lower level of TS when bushes developed more clusters and berries. The highest values of sugar/ acid ratio were found in 'Stanza' (13.2) and the lowest in 'Redpoll' (4.8), both found in berries on 2-year-old shoots. Sugar/acid ratio was 3-5.2 folds higher compared to those obtained by Zorenc et al. (2017), who studied the contents of primary metabolites in three currant cultivars, primarily due to the high level of TS.

A similar pattern was recorded for vitamin $\mathrm{C}$ values. All cultivars had a higher level of vitamin $C$ in berries on 2-year-old shoots. Early-ripening cultivars had higher values of vitamin $\mathrm{C}$ compared to mediumand late-ripening cultivars. Berk et al. (2020) recorded that the content of vitamin $\mathrm{C}$ varied depending on the ripening stages. Redalen (1993) found that the ascorbic acid content of black currants is reduced by elevated temperature. The highest content of this vitamin was found in 'Stanza' ( $66.9 \mathrm{mg} \cdot 100 \mathrm{~g}^{-1}$ on 2-year-old shoots) and the lowest in 'London Market' $\left(24.6 \mathrm{mg} \cdot 100 \mathrm{~g}^{-1}\right.$ on 3 -year-old shoots). A similar low value of vitamin $\mathrm{C}$ was recorded by Pantelidis et al. (2007) in 'London Market'. According to Kevers et al. (2014), environmental conditions, growing systems and genotypes have strong influence on the vitamin C content in berries. Similarly, Vagiri et al. (2013) noticed that the genotype affected the total level of vitamin $\mathrm{C}$ the most $(50 \%)$, followed by locality (17.1\%) and growth conditions (9.3\%). Crus-Rus et al. (2010) established that the synthesis of vitamin $\mathrm{C}$ depended on age, type of plant tissue and cell compartment.

\section{Determination of total phenols, total anthocyanin and anthocyanin aglycone contents}

Content of total phenols ranged from $101.2 \mathrm{mg}$ $\mathrm{GAE} \cdot 100 \mathrm{~g}^{-1} \mathrm{FW}$ ('Makosta') to $325.2 \mathrm{mg} \mathrm{GAE} \cdot 100 \mathrm{~g}^{-1}$ FW ('Redpoll') (Table 4) and was much higher compared to values noted in some studies (Gavrilova et al. 2011; Cristina et al. 2013). The highest values were found in 'Redpoll' (325.2 mg GAE $100 \mathrm{~g}^{-1}$ ) in the berries on older shoots, while 'Makosta' had the lowest (101.2 mg $\left.\mathrm{GAE} \cdot 100 \mathrm{~g}^{-1} \mathrm{FW}\right)$ on the same shoots. Moreover, Giongo et al. (2008) recorded significantly higher values of total phenols in berries of 'Redpoll' compared to other red currant cultivars. A significant variation in the total phenol values among black currant cultivars was also described by Krüger et al. (2011). Milivojević et al. (2012) recorded lower contents of total phenols in the same red currant cultivars and under the same environmental conditions. This discrepancy might be due to the different years of study and the fact that bushes were in the period of full production. In the current study, all cultivars had a higher level of total phenols in the berries on older shoots. The older part of bushes stores higher contents of carbohydrates, which influence the synthesis of phenolic compounds (Machida et al. 2019). Late-ripening cultivars had higher contents of total phenols. Earlier harvest dates of cultivars resulted in lower contents of phenolics due to a shorter maturity period (Sahamishirazi et al. 2017). Zorenc et al. (2017) found lower contents of total phenols with late harvest dates. According to Vagiri et al. (2015), phenolic content varied between harvest dates and with the position of the leaf on the shoot.

Total anthocyanin contents ranged between 12.9 and $33.2 \mathrm{mg} \cdot 100 \mathrm{~g}^{-1} \mathrm{FW}$. Cultivar Redpoll (33.2 mg $\cdot 100 \mathrm{~g}^{-1}$ on 3 -year-old wood) had the highest value, while 'Makosta' had the lowest $\left(12.9 \mathrm{mg} \cdot 100 \mathrm{~g}^{-1}\right.$ on 2-year-old wood). Redpoll had the highest level of anthocyanins with the smallest berry weight. Similar observation was reported in another study on black currant and blueberry cultivars by Krüger et al. (2011), who postulated that anthocyanins are mainly localised in the berry skin, and with an increase in fruit size, the surface area/volume ratio decreases together with the concentrations of anthocyanins.

The total anthocyanin contents of the berry fruits were higher compared to the results reported by other authors analysing the same cultivars (Pantelidis et al., 2007). However, Mitić et al. (2011) and Donno et al. (2013) recorded two- to three-fold-higher content of total anthocyanins in 'Rondom', 'Rovada', 'Jonkheer van Tets', Junifer' and 'Redpoll' cultivars. These differences could be genotype dependant, due to agronomic practices or due to the use of a specific solvent for extraction (Djordjević et al., 2010; Nour et al., 2013). According to Wang et al. (2003), environmental pre-harvest temperature (especially warm night/day temperatures) influences the accumulation of anthocyanins in strawberries. In this experiment, four out of the eight studied cultivars had a higher content of total anthocyanins in the berries on 2-year-old shoots. Likewise, it was observed that early-ripening cultivars had a higher content of total anthocyanins in the berries on younger shoots compared to the content in late-ripening cultivars. The difference in the content of total anthocyanins in berries between 2- and 3-year-old shoots was lower in early-ripening cultivars compared to that in the late-ripening cultivars. Mattila et al. (2016) demonstrated a significant negative correlation between berry size and anthocyanin content of red currant cultivars.

Cyanidin and delphinidin were the most ubiquitous anthocyanin aglycones, and their contents varied among cultivars and with the ages of the shoots. All the studied cultivars (except 'Rolan') had higher cyanidin levels compared to delphinidin levels. Cyanidin 3 -xylosylrutinoside is the most common anthocyanin aglycone in red currant berries (Stój et al., 2006; Gavrilova et al., 2011; Milojevic et al., 2012). In acidic conditions, cyanidin and delphinidin are the more stable glycosides of anthocyanidin. The red currant cultivars had a higher level of cyanidin glycosides probably due to the acidic nature of the berries (Khoo et al., 2017). 
Table 4. Contents of secondary metabolites of the 11 studied red currant cultivars (2013-2018).

\begin{tabular}{|c|c|c|c|c|c|c|}
\hline Cultivars & $\begin{array}{l}\text { Age of } \\
\text { shoots }\end{array}$ & Abbreviation & $\begin{array}{c}\text { Total phenolics } \\
\left(\mathrm{mg} \mathrm{GAE} \cdot 100 \mathrm{~g}^{-1}\right)\end{array}$ & $\begin{array}{l}\text { Total anthocyanins } \\
\left(\mathrm{mg} \cdot 100 \mathrm{~g}^{-1}\right)\end{array}$ & $\begin{array}{c}\text { Cyanidin } \\
\left(\mathrm{mg} \cdot 100 \mathrm{~g}^{-1}\right)\end{array}$ & $\begin{array}{r}\text { Delphinidin } \\
\left(\mathrm{mg} \cdot 100 \mathrm{~g}^{-1}\right)\end{array}$ \\
\hline Abbreviation & & & $\mathrm{TPC} \dagger$ & TAC & CYA & DEL \\
\hline \multirow[t]{2}{*}{ Junifer } & $2^{\prime}$ leaf & Jun $2 \neq$ & $156.0 \pm 4.9 \mathrm{de}$ & $21.5 \pm 1.2 \mathrm{bc}$ & $14.2 \pm 0.8 \mathrm{c}$ & $4.5 \pm 0.3 \mathrm{de}$ \\
\hline & $3^{\prime}$ leaf & Jun3 & $165.3 \pm 6.5 \mathrm{de}$ & $16.7 \pm 0.7 \mathrm{c}$ & $10.3 \pm 0.9 \mathrm{~d}$ & $5.1 \pm 0.2 \mathrm{~d}$ \\
\hline \multirow[t]{2}{*}{ Jonkheer Van Tets } & $2^{\prime}$ leaf & - & & & & \\
\hline & $3^{\prime}$ leaf & Jvt3 & $118.2 \pm 6.3 \mathrm{ef}$ & $17.6 \pm 1.7 \mathrm{bc}$ & $9.3 \pm 0.4 \mathrm{de}$ & $3.4 \pm 0.3$ \\
\hline \multirow[t]{2}{*}{ Stanza } & $2^{\prime}$ leaf & Sta2 & $125.6 \pm 5.7$ ef & $20.4 \pm 1.3 b c$ & $10.0 \pm 0.4 \mathrm{~d}$ & $6.0 \pm 0.3 \mathrm{~cd}$ \\
\hline & $3^{\prime}$ leaf & Sta3 & $149.6 \pm 14.3 \mathrm{de}$ & $15.3 \pm 0.7 \mathrm{c}$ & $8.2 \pm 0.6 \mathrm{de}$ & $5.5 \pm 0.5 \mathrm{~d}$ \\
\hline \multirow[t]{2}{*}{ Rondom } & $2^{\prime}$ leaf & Ron2 & $117.4 \pm 1.5$ ef & $19.6 \pm 0.4 \mathrm{bc}$ & $12.3 \pm 1.1 \mathrm{~cd}$ & $5.4 \pm 0.4 \mathrm{~d}$ \\
\hline & $3^{\prime}$ leaf & Ron3 & $136.3 \pm 2.7 \mathrm{e}$ & $16.5 \pm 3.3 \mathrm{c}$ & $10.3 \pm 0.6 \mathrm{~d}$ & $7.3 \pm 0.2 \mathrm{c}$ \\
\hline \multirow[t]{2}{*}{ Lon Mar } & $2^{\prime}$ leaf & Lok2 & $150.0 \pm 4.6 \mathrm{de}$ & $15.4 \pm 1.1 \mathrm{c}$ & $8.4 \pm 0.2 \mathrm{de}$ & $5.5 \pm 0.4 \mathrm{~d}$ \\
\hline & $3^{\prime}$ leaf & Lok3 & $172.0 \pm 12.3 \mathrm{~d}$ & $14.2 \pm 0.7 \mathrm{c}$ & $6.5 \pm 0.2 \mathrm{e}$ & $6.6 \pm 0.2 \mathrm{~cd}$ \\
\hline \multirow[t]{2}{*}{ Rolan } & $2^{\prime}$ leaf & - & & & & \\
\hline & $3^{\prime}$ leaf & Rol3 & $174.5 \pm 4.9 \mathrm{~d}$ & $19.2 \pm 1.5 \mathrm{bc}$ & $4.2 \pm 0.3 \mathrm{e}$ & $14.2 \pm 0.3 \mathrm{a}$ \\
\hline \multirow[t]{2}{*}{ Makosta } & 2 ' leaf & Mak2 & $101.2 \pm 8.3 \mathrm{f}$ & $12.9 \pm 0.9 \mathrm{c}$ & $7.0 \pm 0.6 \mathrm{de}$ & $4.3 \pm 0.4 \mathrm{de}$ \\
\hline & $3^{\prime}$ leaf & Mak3 & $128.2 \pm 8.3$ ef & $14.3 \pm 1.2 \mathrm{c}$ & $6.2 \pm 0.2 \mathrm{e}$ & $3.2 \pm 0.2 \mathrm{e}$ \\
\hline \multirow[t]{2}{*}{ Mirana } & $2^{\prime}$ leaf & Mir2 & $119.8 \pm 3.7$ ef & $17.9 \pm 0.6 \mathrm{bc}$ & $11.2 \pm 0.5 \mathrm{~cd}$ & $6.2 \pm 0.2 \mathrm{~cd}$ \\
\hline & $3^{\prime}$ leaf & Mir3 & $149.2 \pm 3.6 \mathrm{de}$ & $23.5 \pm 3.1 b c$ & $15.2 \pm 0.8 \mathrm{bc}$ & $8.1 \pm 0.5 b c$ \\
\hline \multirow[t]{2}{*}{ Slovakia } & $2^{\prime}$ leaf & - & & & & \\
\hline & $3^{\prime}$ leaf & Slo3 & $117.2 \pm 6.5$ ef & $22.2 \pm 1.2 b c$ & $17.9 \pm 0.4 b$ & $3.5 \pm 0.2 \mathrm{e}$ \\
\hline \multirow[t]{2}{*}{ Rovada } & $2^{\prime}$ leaf & Rov2 & $206.8 \pm 13.4 \mathrm{c}$ & $24.9 \pm 0.6 \mathrm{~b}$ & $17.4 \pm 0.6 \mathrm{bc}$ & $6.3 \pm 0.5 \mathrm{~cd}$ \\
\hline & $3^{\prime}$ leaf & Rov3 & $239.5 \pm 8.6 \mathrm{~b}$ & $31.4 \pm 1.0 \mathrm{ab}$ & $22.2 \pm 0.4 \mathrm{a}$ & $8.2 \pm 0.3 \mathrm{bc}$ \\
\hline \multirow[t]{2}{*}{ Redpoll } & $2^{\prime}$ leaf & Red2 & $299.8 \pm 10.4 \mathrm{a}$ & $25.4 \pm 1.6 \mathrm{ab}$ & $17.5 \pm 0.9 \mathrm{bc}$ & $7.2 \pm 0.4 \mathrm{c}$ \\
\hline & $3^{\prime}$ leaf & Red3 & $325.2 \pm 23.5 \mathrm{a}$ & $33.2 \pm 3.3 \mathrm{a}$ & $20.1 \pm 0.6 \mathrm{ab}$ & $9.2 \pm 0.2 b$ \\
\hline LSD & & & 31.2 & 7.9 & 3.6 & 1.5 \\
\hline
\end{tabular}

Data shown are means \pm standard deviations of three replications. Different letters in columns indicate a significant difference between cultivars according to Duncan's test at the $5 \%$ level $(p<0.05)$.

$\$$ Abbreviations correspond to the score plots in principal component analysis (PCA) (Figure 4A).

$\dagger$ Abbreviations correspond to the factor loadings in PCA (Figure 4B).

However, many researchers did not find delphinidin in red currant in their studies (Milivojevic et al., 2012; Veberic et al., 2015; Jara-Palacios et al., 2019). Contents of cyanidin glycosides ranged between 4.2 ('Rolan') and 20.1 ('Redpoll') $\mathrm{mg} \cdot 100 \mathrm{~g}^{-1} \mathrm{FW}$, while values of delphinidin ranged between 3.2 ('Makosta') and 14.2 ('Rolan') $\mathrm{mg} \cdot 100 \mathrm{~g}^{-1} \mathrm{FW}$. Late-ripening cultivars had higher values of cyanidin in berries on 3 -year-old shoots, while early-ripening cultivars had higher contents in berries on 2-year-old shoots. According to Turturică et al. (2015), the stability of the anthocyanin aglycones depends on the type of anthocyanin pigment, the copigments, weather conditions, enzymes and oxygen.

\section{PCA of the cultivars}

PCA was used to establish similarity/dissimilarity among the 2- and 3-year-old shoots from different red currant cultivars. PCA was applied on the data matrix of 19 samples (eight currant cultivars that bear berries on both 2- and 3-year-old wood, and three cultivars that have berries on just 3 -year-old wood) $\times 24$ traits (phenology, morphology, pomology and chemistry), while using the covariance matrix with auto-scaling. All studied traits were included except for the total number of clusters per bush, total yield per bush, and YE due to the inability to separate the results between 2- and 3-year-old wood specimens.

The obtained six-component model explained $86.89 \%$ of all the data variations. The first principal component $(\mathrm{PC} 1)$ represents the greatest degree of variance $(36.04 \%)$, while the second PC accounted for $15.13 \%$, the third for $13.81 \%$, the fourth for $10.75 \%$, the fifth for $5.88 \%$, and the sixth for $4.28 \%$ of the total variation in the data.

Figure 4A shows the projection of the investigated 2- and 3-year-old woods in the current cultivars on the PC1/PC2 plane. The existence of two groups along the PC2 axis is noticeable, with 2-year-old wood is separated from the 3 -year-old wood. From the PCA loading plot, it is possible to identify the most influential variables responsible for the clustering (Figure 4B). Bud burst (BB), blooming time (BT), harvesting time (HT), cluster 

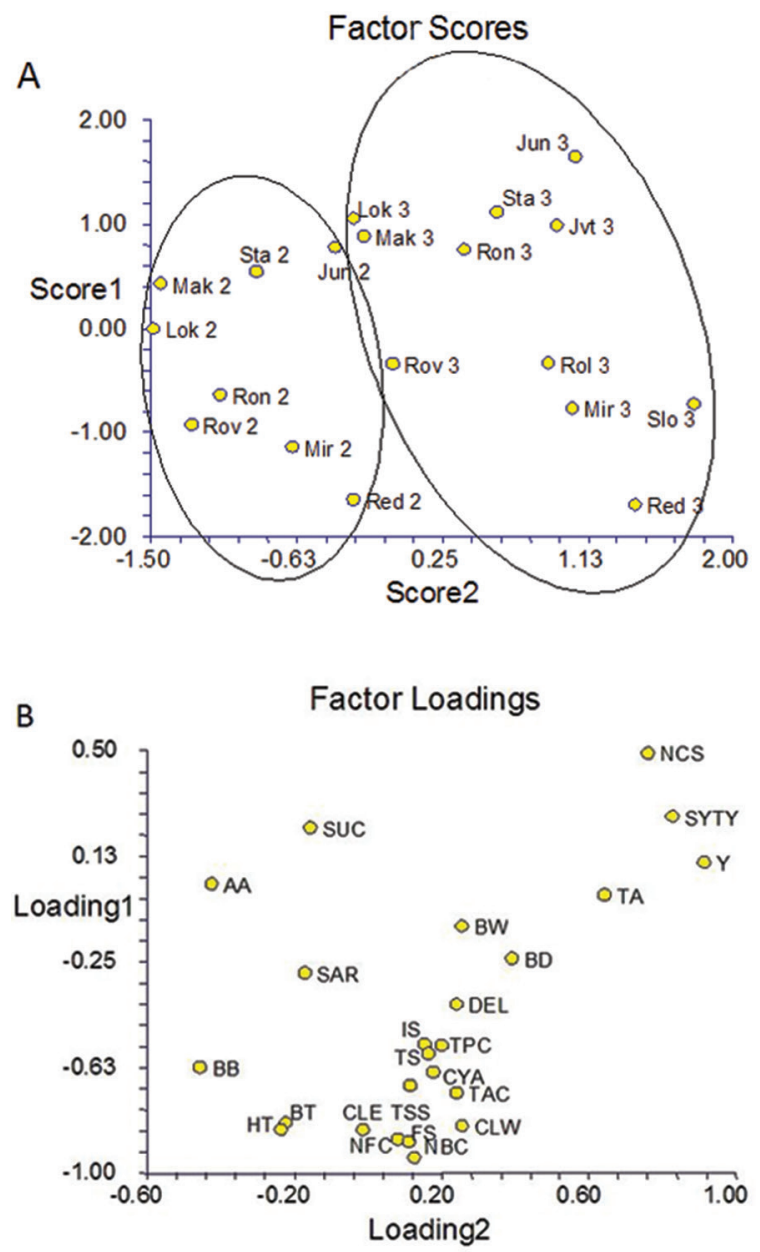

Figure 4. (A) Principal component (PC) scores and (B) loading plot of the traits studied in 2- and 3-year-old shoots f 11 red currant cultivars. Abbreviations used in panel (A): 'Junifer', 2' leaf - Jun2; 'Junifer', 3' leaf Jun3; 'Jonkheer van Tets', 3' leaf - Jvt3; 'Stanza', 2' leaf - Sta2; 'Stanza', 3' leaf - Sta3; 'Rondom', 2' leafRon2; 'Rondom', 3' leaf - Ron3; 'London market', 2' leaf - Lok2; 'London market', 2' leaf - Lok3; 'Rolan', 3' leaf-Rol3; 'Makosta', 2' leaf - Mak2; 'Makosta', 3' leaf-Mak3; 'Mirana', 2' leaf-Mir2; 'Mirana', 3' leafMir3; 'Slovakia', 3' leaf - Slo3; 'Rovada', 2' leaf Rov2; 'Rovada', 3' leaf - Rov3; 'Redpoll', 2' leaf - ed2; 'Redpoll', 3' leaf - Red3). Abbreviations in panel (B) correspond to the cultivars/shoots and traits given in Tables 1-4.

length (CLE), number of flowers per cluster (NFC), and number of berries per cluster (NBC) were the most important factors for the discrimination of 2-year-old wood from 3-year-old wood samples. On the other hand, samples from 3-year-old wood were grouped based on their number of clusters per shoot (NCS), TA, yield per shoot (Y) and percentage of shoot yield in total yield (SYTY).

PC1 was mainly attributed to blooming time (0.82), harvesting time (0.84), cluster weight $(0.83)$, cluster length (0.85), number of flowers per cluster (0.88), number of berries per cluster (0.94), fruit set (0.89) and total anthocyanins (0.71). The summarisation of these traits in one component indicated a strong correlation among these traits reciprocally. Similar results for different black, red and white currant cultivars were obtained by Djordjevic et al. (2014), where bud burst, cluster weight, numbers of flowers and berries per cluster and the total anthocyanin content correlated among each other on PC1. PC2 is dominated by the number of clusters per shoot, yield per shoot and percentage of shoot yield in total yield, with strong factor loadings of 0.76, 0.91 and 0.82, respectively. Rakonjac et al. (2015) also found a significant correlation between yield and cluster number per shoot. The largest score of PC3 was due to TS (0.72). PC4, PC5 and PC6 did not have any strong factor loadings.

\section{CONCLUSIONS}

To the best of our knowledge, the current study is the first comprehensive analysis to compare the biological and chemical properties of berries from shoots of different ages in 11 red currant cultivars with different origins and ripening times. All examined cultivars had earlier beginning of all phenological stages, higher yield and higher total phenol levels on 3-year-old shoots, compared to the same properties of 2-year-old shoots, while clusters and berries had better physical attributes, higher TSS and greater contents of total anthocyanins and vitamin $\mathrm{C}$ in younger shoots. PCA showed that the most important variables that distinguish 2-yearold shoots from 3-year-old shoots were those related to phenology data, cluster traits, TA and yields. After evaluation of the results, the authors of this study suggest that the following cultivars are suitable for growing in Serbian or similar agro-ecological (temperate) conditions: 'Junifer', because it stood out with the highest generative potential; 'Mirana', which was singled out by the highest sugar content and sugar/ acid ratio in the berries; cultivar 'Redpoll' due to the highest physical traits of cluster and berry; 'Slovakia' due to its highest yield and YE; and 'Rovada' due to the highest level of secondary metabolites in its berries.

Obtained results are giving possibility to the producers in the future to plan agrotechnical measurements and project fruit load, especially by pruning, in order to obtain higher yields and/or enhance higher level of health promoting phytochemicals.

\section{FUNDING}

This study was supported by the Ministry of Education, Science and Technological Development of the Republic of Serbia and Faculty of Agriculture (grant number 451-03-68/2020-14/200116).

\section{AUTHOR CONTRIBUTIONS}

B.S.D. and M.M.F.A. designed the experiment. G.D.Z. prepared samples for laboratory analysis. B.S.D. and 
M.M.F.A. equally wrote the paper. D.B.D. performed statistical analysis. M.O.M. performed proof reading and manuscript correction.

\section{CONFLICT OF INTEREST}

The authors declare no conflict of interest.

\section{REFERENCES}

Berk, S., Gundogdu, M., Tuna, S., and Tas, A. (2020). Role of maturity stages on phenolic compounds and organic acids contents in red currant fruits. International Journal of Fruit Science, doi: 10.1080/ 15538362.2020.1774476.

Brennan, R. M. (2008). Currants and gooseberries. In J. F. Hancock (Ed.), Temperate fruit crop breeding: Germplasm to genomics (pp. 177-196). Dordrecht, Netherlands: Springer.

Ciornea, E., Dumitru, G., Cojocaru, S. I., Cojocaru, D., And Oniciuc, M.V. (2009). A biochemical study on the Vaccinium myrtillus, Ribes rubrum and Ribes nigrum fruits from the spontaneous flora. Secţiunea Genetică şi Biologie Moleculară, 10, 81-88.

Cristina, P., Alina, I., And Cristina, M. (2013). Production and quality potential of different black and red currant cultivars in Baneasa Research Station condition. Journal of Horticulture, Forestry and Biotechnology, 17(4), 76-79.

Crus-Rus, E., Botella, M. A., Valpuesta, V., And Gomez-Jimenez. M. C. (2010). Analysis of genes involved in L-ascorbic acid biosynthesis during growth and ripening of grape berries. Journal of Plant Physiology, 167(9), 739-748.

Djordjević, B., Rakonjac, V., Fotirić Akšić, M., ŠAvikin, K., And Vulić, T. (2014). Pomological and biochemical characterization of European currant berry (Ribes sp.) cultivars. Scientia Horticulturae, 165, 156-162.

Djordjevic, B., Šavikin, K., Zdunić, G., Janković, T., Vulić, T., Oparnica, Č., And Radivojević, D. (2010). Biochemical properties of red currant varieties in relation to storage. Plant Foods for Human Nutrition, 65(4), 326-332.

Donno, D., Cavanna, M., Beccaro, G. L., Mellano, M. G., Torello Marinoni, D., Cerutti, A. K., And Bounous, G. (2013). Currants and strawberries as bioactive compound sources: Determination of antioxidant profiles with HPLC-DAD/MS. Journal of Applied Botany and Food Quality, 86, 1-10.

Ersoy, N., Kupe, M., Gundogdu, M., Ilhan, G., And Ercisli, S. (2018). Phytochemical and antioxidant diversity in fruits of currant (Ribes spp.). Notulae Botanicae Horti Agrobotanici Cluj-Napoca, 46(2), 381-387.

European Pharmacopoeia 6.0 (2008). Council of Europe. Strasbourg Cedex, France, pp. 1307-1308.

Faostat. (2020). Retrieved from http://faostat.fao.org/ beta/en/\#data/QC.
Gavrilova, V., Kajdzanoska, M., Guamovski, V., And STEFova, M. (2011). Separation, characterization and quantification of phenolic compounds in blueberries and red and black currants by HPLC-DAD-ESI-MS. Journal of Agricultural and Food Chemistry, 59, 4009-4018.

Georgiev, D., Dinkova, H., And Georgieva, M. (2008). Study of newly introduced cultivars of black and red currant. Paper presented at the International Scientific Conference "Sustainable Fruit Growing: From Plant to Product", Latvia, 44-53.

Giongo, L., Grisenti, M., Eccher, M., Palchetti, A., VRhovsek, U., And Mattivi, F. (2008). Horticultural and nutritional qualities of white, red and black currants. Acta Horticulturae, 777, 167-172.

Gündeșli, M. A., Korkmaz, N., and OKatan, V. (2019). Polyphenol content and antioxidant capacity of berries: A review. International Journal of Agriculture, Forestry and Life Sciences, 3(2), 350-361.

Heijerman, G., and Gessel, V. G. (2020). Higher profits with planting hole treatment in red currant. Acta Horticulturae, 1277, 239-244.

Hidalgo, G. I., And Almajano, M. P. (2017). Red fruits: Extraction of antioxidants, phenolic content, and radical scavenging determination: A review. Antioxidants, 6(1), 7. doi: 10.3390/antiox6010007.

Jara-Palacios, J., Santisteban, A., Gordillo, B., Hernanz, D., Heredia, F., and Escudero-Gilete, L. (2019). Comparative study of red berry pomaces (blueberry, red raspberry, red currant and blackberry) as source of antioxidants and pigments. European Food Research and Technology, 245, 1-9.

Kaldmäe, H., Kikas, A., Arus, L., and Libek, A. V. (2013). Genotype and microclimate conditions influence ripening pattern and quality of black currant (Ribes nigrum L.) fruit. ZemdirbysteAgriculture, 100(2), 167-174.

Karhu, S., Bles, C., Laine, K., and Palonen, P. (2020). Improving the performance of red and white currants in high latitude conditions by training methods. Acta Horticulturae, 1277, 225-232.

Kevers, C., Pincemail, J., Defraigne, J. O., and Dommes, J. (2014). Antioxidant capacity of small dark fruits: Influence of cultivars and harvest time. Journal of Berry Research, 4, 97-105.

Khoo, H. E., Azlan, A., Tang, S. T., and Lim, S. M. (2017). Anthocyanidins and anthocyanins: Colored pigments as food, pharmaceutical ingredients, and the potential health benefits. Food \& Nutrition Research, 61(1), 1361779, doi: 10.1080/16546628.2017.1361779.

Krüger, E., Dietrich, H., Hey, M., And Patz, C. D. (2011). Effects of cultivar, yield, berry weight, temperature and ripening stage on bioactive compounds of black currants. Journal of Applied Botany and Food Quality, 84, 40-46.

Machida, S., Mukai, S., Kono, R., Funato, M, Saito, H., and Uchiyama, T. (2019). Synthesis and comparative structure-activity study of carbohydrate-based 
phenolic compounds as $\alpha$-glucosidase inhibitors and antioxidants. Molecules, 24(23), 4340, doi: 10.3390/ molecules24234340.

Mattila, P., Hellström, J., Karhu, S., Pihlava, J. M., and Vetelärnen, M. (2016). High variability in flavonoid contents and composition between different North-European currant (Ribes spp.) varieties. Food Chemistry, 204, 14-20.

Mikulic-Petkovsek, M., Koron, D., and Veberic, R. (2016). Quality parameters of currant berries from three different cluster positions. Scientia Horticulturae, 210, 188-196.

Milivojevic, J., Slatnar, A., Mikulic-Petkovsek, M., Stampar, F., Nikolic, M., and Veberic, R. (2012). The influence of early yield on the accumulation of major taste and health-related compounds in black and red currant cultivars (Ribes spp.). Journal of Agriculture and Food Chemistry, 60, 2682-2691.

MilošEvić, T., AND MilošEvić, N. (2018). Vegetative growth, productivity, berry quality attributes and leaf macronutrients content of currants as affected by species and cultivars. Erwerbs-Obstbau, 60, 53-65.

Mitić, M., Obradović, M., Kostić, D., Micić, R., AND Paunović, D. (2011). Phenolic profile and antioxidant capacities of dried red currant from Serbia, extracted with different solvent. Food Science and Biotechnology, 20(6), 1625-1631.

Nour, V., Stampar, F., Veberic, R., and Jakopic, J. (2013). Anthocyanins profile, total phenolics and antioxidant activity of black currant ethanolic extracts as influenced by genotype and ethanol concentration. Food Chemistry, 141(2), 961-966.

Nyman, N. A., and Kumpulainen, J. T. (2001). Determination of anthocyanidins in berries and red wine by high-performance liquid chromatography. Journal of Agricultural and Food Chemistry, 49, 4183-4187.

Okatan, V. (2020). Antioxidant properties and phenolic profile of the most widely appreciated cultivated berry species: A comparative study. Folia Horticulturae, 32(1), 79-85.

Orsavova, J., Hlaváčoví, I., MlČeK, J., Snopek, L., AND Mišurcová, L. (2019). Contribution of phenolic compounds, ascorbic acid and vitamin E to antioxidant activity of currant (Ribes L.) and gooseberry (Ribes uva-crispa L.) fruits. Food Chemistry, 284, 323-333.

Palacio, S., Comarerro, J. J., Maestro, M., All, A. Q., Lahoz, E., and Monserrat-Marti, G. (2018). Are storage and tree growth related? Seasonal nutrient and carbohydrate dynamics in evergreen and deciduous Mediterranean oaks. Trees-Structure and Function, 32(3), 777-790.

Pantelidis, G. E., Vasilakakis, M., Manganaris, G. A., and Diamantidis, G. (2007). Antioxidant capacity, phenol, anthocyanin and ascorbic acid contents in raspberries, blackberries, red currants, gooseberries and Cornelian cherries. Food Chemistry, 102, $777-783$.

Paprstein, F., Sedlak, J., and Kaplan, J. (2016). Rescue of red and white currant germplasm in the Czech Republic. Acta Horticulturae, 1133, 49-52.

Rakonjac, V., Diordjevic, B., Fotirić Akšić, M, Vulić, T., AND DJURović, Đ. (2015). Estimation of variation and correlation analysis for yield components in black currant cultivars. Genetika, 47(3), 785-794.

ReDAlen, G. (1993). Black currants grown in simulated climates in growth chambers. Acta Horticulturae, $352,213-216$.

Rubinskiene, M., Viskelis, P., Jasutiene, I., Duchovskis, P., AND Bobinas, C. (2006). Changes in biologically active constituents during ripening in black currants. Journal of Fruit and Ornamental Plant Research, 14(2), 236-246.

Sahamishirazi, S., Moehring, J., Claupein, W., and Graeff-Hoenninger, S. (2017). Quality assessment of 178 cultivars of plum regarding phenolic, anthocyanin and sugar content. Food Chemistry, 241, 694-701.

Santos-Buelga, C., Mateus, N., and DE Freitas, V. (2014). Anthocyanins. Plant pigments and beyond. Journal of Agriculture and Food Chemistry, 62, 6879-6884.

ŠAvikin, K., Mikulič-Petkovšek, M., Djordjević, B., Zdunić, G., Janković, T., Duurović, D., And Veberič, R. (2013). Influence of shading net on polyphenol profile and radical scavenging activity in different varieties of black currant berries. Scientia Horticulturae, 160, $20-28$.

Sønsteby, A., Roos, M. U., And Heide, M. O. (2017). Influence of controlled nutrient feeding during floral initiation and berry development on shoot growth, flowering and berry yield and quality in black currant (Ribes nigrum L.). Scientia Horticulturae, 225, 638-645.

Stanus, V., Bendokas, V., Rugienius, R., Sasnauskas, A., Frercks, B., MažEIKIENĖ, I., AND ŠIKŠnianas, T. (2019). Management of anthocyanin amount and composition in genus Ribes using interspecific hybridisation. Scientia Horticulturae, 247, $123-129$.

Stós, A., Malik, A., And Targoński, Z. (2006), Comparative analysis of anthocyanin composition of juices obtained from selected species of berry fruits. Polish Journal of Food and Nutrition Sciences, 56(4), 401-407.

TuRTURică,M.,OANCEA,A.M.,RÂPEANU, G., ANDBAHRim,R. (2015). Anthocyanins: Naturally occurring fruit pigments with functional properties. The Annals of the University Dunarea de Jos of Galati Fascicle VI: Food Technology, 39(1), 9-24.

UPOV CODE: RIBES_RUB. (2012). Protocol for distinctness, uniformity and stability tests Ribes 
rubrum L. Red currant, White currant. The Community Plant Variety Office (CPVO) -TP/052/2.

Vagiri, M., Conner, S., Stewart, D., Andersson, S., Verrall, S., Johansson, E., and Rumpunen, K. (2015). Phenolic compounds in blackcurrant (Ribes nigrum L.) leaves relative to leaf position and harvest date. Food Chemistry, 172, 135-142.

VAgiri, M., Ekholm, A., ÖBerG, E., Johansson, E., Andersson, S. C., And Rumpunen, K. (2013). Phenols and ascorbic acid in black currants (Ribes nigrum L.): Variation due to genotype, location, and year. Journal of Agriculture and Food Chemistry, 61, 9298-9306.

Veberic, R., Slatnar, A., Bizjak, J., Stampar, F., and Mikulic-Petkovsek, M. (2015). Anthocyanin composition of different wild and cultivated berry species. Food Science and Technology, 60(1), 509-517.

WANG, S. Y., Zheng, W., AND MAAs, J. L. (2003). High plant growth temperatures increases antioxidant capacity in strawberry fruit. Acta Horticulturae, 626, 57-63.

Waterman, P., And Mole, S. (1994). Analysis of phenolic plant metabolites (p. 16). Oxford, UK: Blackwell Scientific Publication.

Woznicki, T. L., Heide, O. M., Sønsteby, A., Wold, A. B., AND Remberg, S.F. (2016). Effects of temperature and precipitation on yield and chemical composition of black currant fruits (Ribes nigrum L.). Acta Horticulturae, 1133, 183-188.
Xu, Q.H., Qiu, CH.P., Gaudreau, L., Gosselin,A., DesJardins, Y., Gauthier, L. and Van Sterthem, A. (2016). Effect of root age on growth and yield of red raspberries grown under high tunnel and open field in northern Canadian climate. Acta Horticulture, 1133, 177-182.

YAng, B., Zheng, J., LaAksonen, O., Tahvonen, R., And Kallio, H. (2013). Effects of latitude and weather conditions on phenolic compounds in currant (Ribes spp.) cultivars. Journal of Agriculture and Food Chemistry, 61(14), 3517-3532.

Zdunić, G., Šavikin, K., Pluevluakušić, D., AND DjordjeVić, B. (2016). Black (Ribes nigrum L.) and red currant (Ribes rubrum L.) cultivars. In M. S. J. Simmonds and V. R. Preedy (Eds), Nutritional composition of fruit cultivars (pp. 101-126). Elsevier, Amsterdam: Academic Press.

Zheng, J., Kallio, H., And Yang, B. (2009). Effects of latitude and weather conditions on sugars, fruit acids and ascorbic acid in currant (Ribes sp.) cultivars. Journal of Agricultural and Food Chemistry, 89, 2011-2023.

Zorenc, Z., Veberic, R., Koron, D., Miosic, S., Hutabarat, S., Halbwirth, H., and MikulicPetkovsek, M. (2017). Polyphenol metabolism in differently colored cultivars of redcurrant (Ribes rubrum L.) through fruit ripening. Planta, 246, 217-226.

Received: July 29, 2020; accepted: October 19, 2020. 